\title{
Interactive comment on "A numerical modelling study of the physical mechanisms causing radiation to accelerate tropical cyclogenesisand cause diurnal cycles" by Melville E. Nicholls et al.
}

\section{Anonymous Referee \#1}

Received and published: 19 November 2019

Please find the text in the attachment.

Please also note the supplement to this comment: https://www.atmos-chem-phys-discuss.net/acp-2019-569/acp-2019-569-RC1supplement.pdf

Interactive comment on Atmos. Chem. Phys. Discuss., https://doi.org/10.5194/acp-2019-569, 2019. 